\title{
Pathway for Phloem-Dependent Movement of Pepper Mottle Potyvirus in the Stem of Capsicum annuum
}

\author{
Mahefa Andrianifahanana, Karrie Lovins, Roland Dute, Edward Sikora, and John F. Murphy
}

First, second, fourth, and fifth authors: Department of Plant Pathology; and third author: Department of Botany \& Microbiology, Auburn University, Auburn, AL 36849-5409.

Accepted for publication 16 May 1997.

\begin{abstract}
Andrianifahanana, M., Lovins, K., Dute, R., Sikora, E., and Murphy, J. F. 1997. Pathway for phloem-dependent movement of pepper mottle potyvirus in the stem of Capsicum annuиm. Phytopathology 87:892-898.

Phloem-dependent movement of pepper mottle potyvirus (PepMoV) through Capsicum annuum occurs in a defined pattern through the stem and into uninoculated leaves. The route of movement of PepMoV through the stem of $C$. аппиит 'Early Calwonder' was tracked using immunotissue blot analysis and immunomicroscopy. Virus was shown to move from the inoculated leaf down the stem toward the roots via the external

phloem. At some location between the cotyledonary node and the roots, PepMoV entered the internal phloem through which it rapidly spread upward the length of the stem to the young tissues. Translocation of PepMoV through the stem occurred in an asymmetric fashion, i.e., virus remained on the side of the stem to which the inoculated leaf was attached as it translocated the length of the stem. Spread and accumulation of PepMoV into uninoculated leaves appeared to occur in a source-to-sink pattern similar to that described for the flow of photoassimilates and similar to other virus and viroid-host systems.
\end{abstract}

Plant viruses cause devastating diseases in many crops worldwide $(1,7,40)$, although the degree of damage inflicted on the host plant is generally dependent upon the extent of invasion by the virus. A systemic viral infection can result in reduced crop yields and increased accessibility of the virus to its vector, thereby enhancing the opportunity for plant-to-plant spread of the virus. Systemic infection of a plant also increases the opportunity for transmission of virus through seed and cuttings $(1,41,42,46)$.

There are two general levels of virus movement within a plant: short distance or cell-to-cell and long distance, which is also referred to as systemic or phloem-dependent movement. Cell-to-cell movement occurs via plasmodesmata and typically involves an interaction of one or more viral-encoded factors with the viral nucleic acid, the plasmodesmata, or both $(9,10,12,21,28)$. In some cases, viral-encoded tubules are formed that allow transport of virion from one cell to the next $(24,38,45)$.

Long-distance movement (hereafter referred to as phloemdependent movement) of a virus within a plant generally refers to translocation from the inoculated leaf through the stem to uninoculated leaves and occurs through the plant vasculature, typically the phloem $(21,26,30)$. The pattern of spread throughout a plant is similar for different virus-host systems $(27,29,39)$ and, in each case, virus appears to follow a "source-to-sink" pattern similar to that observed for photoassimilates $(4,27,43)$. In a source-to-sink pattern of translocation, mature leaves that are photosynthetically active produce and supply photoassimilates, i.e., serve as sources of photoassimilates, while young leaves that are not photosynthetically active serve as sinks for photoassimilates. Thus, the pattern of flow for photoassimilates is from sources to sinks.

Studies on potyvirus movement have shown that the coat protein of tobacco etch virus (TEV) plays a role in cell-to-cell movement (15), while TEV coat protein and helper component-proteinase

Corresponding author: J. F. Murphy; E-mail address: jmurphy@acesag.auburn.edu

Publication no. P-1997-0627-01R

(C) 1997 The American Phytopathological Society protein are involved in systemic movement $(11,16)$. There appear to be distinct domains within the TEV coat protein associated with its movement function. A mutation within the core domain that affects assembly of virus particles rendered TEV unable to move cellto-cell, while mutations within $\mathrm{N}$-termini, C-termini, or both resulted in inhibition of systemic movement $(15,16)$.

We initiated studies to determine the route of spread of pepper mottle potyvirus (PepMoV) within Capsicum annuum plants. As shown in this report, phloem-dependent movement of PepMoV within a susceptible Capsicum spp. follows a defined route consisting of external and internal phloem within the stem with rapid spread to young tissues occurring via internal phloem.

\section{MATERIALS AND METHODS}

Host source and growth conditions. C. annuum 'Early Calwonder' seeds were allowed to germinate in petri dishes (34) prior to being transferred to Pro-Mix soilless potting medium (Premier Peat, Rivière-du-Loup, Québec, Canada) in individual 4-inch sterilized pots. Plants were grown in a temperature-controlled greenhouse (average temperatures of $28^{\circ} \mathrm{C}$ day $/ 21^{\circ} \mathrm{C}$ night); from September through April, metal halide lighting was used for $14 \mathrm{~h} /$ day.

Virus isolate and inoculations. PepMoV strain V-1182, provided by T. A. Zitter (Cornell University, Ithaca, NY), was maintained in Nicotiana tabacum 'Kentucky 14' and purified according to Murphy et al. (35). Inoculum used in all experiments consisted of purified PepMoV diluted to a final concentration of $25 \mu \mathrm{g} / \mathrm{ml}$ in $50 \mathrm{mM}$ potassium phosphate buffer, $\mathrm{pH} 7.5$, containing $1 \mathrm{mg} / \mathrm{ml}$ of Carborundum.

Phloem-dependent movement of PepMoV relative to phyllotactic positions of leaves. 'Early Calwonder' plants were inoculated when leaves 11 and 12 were 1 to $2 \mathrm{~cm}$ in length. Inoculum was applied to leaf 1 (the oldest true leaf) by rub-inoculation of the upper surface of the leaf. Plants used as mock-inoculated controls were treated similarly, but without addition of virus. Leaves (petiole and blade) from three PepMoV-inoculated plants and one mock-inoculated plant were tested at each sampling period. Plant samples were collected at 12 -h intervals beginning 1 day postinoc- 
ulation (dpi) through $7 \mathrm{dpi}$, and then at 10, 12, 18, 21, and 39 dpi. Samples were tested for the presence of PepMoV coat protein antigen (hereafter referred to as PepMoV $\mathrm{CP}$ ) by immunotissue blot analysis or indirect enzyme-linked immunosorbent assay (ELISA).

For immunotissue blot analysis, each leaf was tightly rolled transversely, and a single cross-sectional cut was made across the rolled leaf using a razor blade. The cut was made at a distance of approximately one-third the length of the leaf blade from its base. For petioles, single cuts were made across their axes. Tissue prints were generated from tissue sections by pressing the cut surface of the tissue directly onto nitrocellulose membranes (Schleicher \& Schuell, Inc., Keene, NH) that were treated with $0.2 \mathrm{M} \mathrm{CaCl}_{2}$ prior to blotting (20). Tissue prints were allowed to air-dry and were stored at $4{ }^{\circ} \mathrm{C}$ until the end of the experiment, at which time all samples were analyzed at the same time under the same conditions. PepMoV CP was detected in tissue blots (34) using antiPepMoV immunoglobulin ( $\mathrm{Ig})$ as primary antibody $(1 \mu \mathrm{g} / \mathrm{ml})$ and goat anti-rabbit Ig conjugated to alkaline phosphatase as secondary antibody (diluted 1:7,000). The presence of alkaline phosphatase was detected using a colorimetric reaction system (25).

Leaf samples were collected for ELISA as described for immunotissue blot analysis, except that the leaf blade and petiole were processed as a single sample. Each leaf was weighed prior to being ground in $50 \mathrm{mM}$ carbonate buffer, $\mathrm{pH} 9.6$, using a motorized leaf squeezer. Each sample was added to the microtiter plate at a final dilution of 1:10 (gram of tissue/milliliters of buffer) and incubated for at least $12 \mathrm{~h}$ at $4^{\circ} \mathrm{C}$. Anti-PepMoV Ig was used at 0.5 $\mu \mathrm{g} / \mathrm{ml}$ and allowed to incubate for at least $12 \mathrm{~h}$ at $4^{\circ} \mathrm{C}$. Goat antirabbit Ig conjugated to alkaline phosphatase (Sigma Chemical Co., St. Louis) was used as recommended by the manufacturer and incubated for 3 to $4 \mathrm{~h}$ at $37^{\circ} \mathrm{C}$. Substrate reactions $(1.0 \mathrm{mg} / \mathrm{ml}$ of paranitrophenyl phosphate dissolved in $10 \%$ diethanolamine, $\mathrm{pH}$ 9.8) were allowed to develop until purified virus standards achieved specific absorbance values $(405 \mathrm{~nm})$ determined on a Dynatech MR 700 microplate reader (Dynatech Laboratories Inc., Chantilly, VA). The use of purified virus standards allowed standardization of the procedure so that comparisons could be made between microtiter plates analyzed either on the same day or different days.

Phloem-dependent movement of PepMoV within the stem. Immunotissue blot detection of PepMoV CP accumulation was used to track phloem-dependent movement of PepMoV in the stems of 'Early Calwonder' plants through time. This approach was chosen because it is highly sensitive and, perhaps most importantly, it provides information on relative distribution of viral antigen within tissues. Although this approach tracks PepMoV CP that has accumulated to detectable levels, presumably in PepMoV-infected stem tissues, we recognize that it does not necessarily provide an indication of the leading edge of infection.

PepMoV was inoculated onto leaf 1 of 'Early Calwonder' plants that were at the 11- to 12-leaf stage of growth. Plants were analyzed at 4-h intervals from 2 through 6 dpi. At each time interval, tissue prints were generated from the base of the hypocotyl (soil line), the middle portion of the hypocotyl, directly below and above the cotyledonary node, halfway between the cotyledonary node and the node of the first leaf, and at all internodes between leaf pairs above the inoculated leaf. Single cuts were made across the stem axis using a sharp razor blade that was cleaned with $70 \%$ ethanol and rinsed with distilled water between uses. The cut surface of the stem was pressed onto nitrocellulose membranes as described in the preceding section. Three PepMoV-inoculated plants and one mock-inoculated plant were used at each sampling period. Tissue prints were allowed to air-dry and were stored at $4^{\circ} \mathrm{C}$ until the end of the experiment. All samples were analyzed for the presence of PepMoV CP at the same time and under the same conditions as described above.

Microscopy. Inoculation of plants with PepMoV was as described in preceding sections. Axial segments were collected from the same portions of the stem as described for generation of tissue prints.
For anatomical studies, stem segments (about $0.5 \mathrm{~cm}$ in length) were marked at the top of each segment with india ink to track orientation and submerged in $0.1 \mathrm{M}$ potassium phosphate buffer,

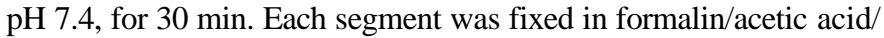
alcohol for $2 \mathrm{~h}$ under vacuum. Segments were dehydrated in a tertiary butyl alcohol series and infiltrated and embedded in paraffin (22). To provide a specimen showing typical stem anatomy, a segment taken from the internode between the cotyledonary node and the first true leaf was sectioned using a Leitz 1512 rotary microtome (Leitz Wetzlar GmbH, Germany) set at $10 \mu \mathrm{m}$. The other segments were retained for a detailed investigation of the vasculature of Capsicum now in progress (K. Lovins, R. Dute, and J. F. Murphy, unpublished data). The sections were adhered to glass slides overnight on a slide warmer at $40^{\circ} \mathrm{C}$ using Haupt's adhesive (Carolina Biological Supply Co., Burlington, NC) and 4\% formalin (22). Sections were hydrated and stained for 5 min with $0.5 \%$ aqueous toluidine blue, a metachromatic stain, for identification of xylem and phloem tissues (36). After a gentle washing in deionized water, sections were rapidly dehydrated to prevent destaining and then treated with the following solutions each for $3 \mathrm{~min}$ at room temperature: Hemo De (Fisher Scientific Co., Norcross, GA):100\% ethanol (1:1), Hemo De:cedar oil (1:1), and two changes of Hemo De. Sections were then mounted using Permount (Fisher Scientific Co.) with overnight incubation at $40^{\circ} \mathrm{C}$ on a slide warmer. Sections were viewed and photographed using a Nikon 84200 Optiphot microscope (Nikon Corp., Tokyo).

Stem segments cut as free-hand sections were fixed for $2 \mathrm{~h}$ at $4^{\circ} \mathrm{C}$ in $4 \%$ paraformaldehyde in $50 \mathrm{mM}$ sodium phosphate buffer, $\mathrm{pH} 7.4$ (14). The fixed stem segments were rinsed five times with $0.1 \mathrm{M}$ sodium phosphate buffer, $\mathrm{pH} 7.4$, for $5 \mathrm{~min}$ each, and then stored in the same buffer at $4^{\circ} \mathrm{C}$ until analyzed. Detection of PepMoV CP within the stem sections was by reaction with antiPepMoV Ig (final concentration of $2 \mu \mathrm{g} / \mathrm{ml}$ ) followed by immunogold labeling and silver enhancement according to the manufacturer's specifications (Sigma Technical Bulletin SE-1; Sigma Chemical Co.). Samples were viewed and photographed using a Nikon Optiphot microscope (Nikon Corp.). These same free-hand sections also provided supplementary information for the anatomical investigation.

\section{RESULTS}

Phloem-dependent movement of PepMoV relative to phyllotactic positions of leaves. The arrangement of leaves on the stem (phyllotaxis) varied with node number. The two cotyledons were inserted opposite one another at the cotyledonary node. The first two true leaves generally were inserted opposite one another and at right angles to the cotyledons; however, sometimes their insertion was alternate, i.e., one leaf per node. The immediately succeeding leaf pair, although inserted one to a node, tended to be at right angles to the previous pair, but as further leaves formed (one at a node), the leaf arrangement became a spiral with a $3 / 8$ phyllotaxy. This means that it took eight leaves and three revolutions about the stem before one leaf was exactly superimposed on another. For experimental purposes, true leaves were numbered in decreasing order of age starting from leaf 1 (the oldest true leaf) to leaf 12. Taking into account the changing nature of leaf insertion and the fact that young Capsicum stems were four-sided, the following groups of leaves were arranged in approximate vertical rows: $1 / 6 / 9,3 / 8 / 11,2 / 5 / 10$, and 4/7/12.

The phloem-dependent movement of PepMoV into petioles and leaves of 'Early Calwonder' plants was determined over a period of 39 days by immunotissue blot analysis and ELISA. The two procedures revealed a similar pattern of spread of PepMoV into different leaves; however, detection of PepMoV CP by immunotissue blot analysis occurred 1 to 2 days earlier in all leaves relative to ELISA (data not shown) and allowed us to obtain distinct data on PepMoV CP accumulation in the petiole versus the leaf 
blade. Immunotissue blot analysis is presented in Table 1 and is representative of four separate experiments.

PepMoV CP was first detected in the petiole and leaf blade of the inoculated leaf by $4.5 \mathrm{dpi}$ (Table 1 ). The first uninoculated leaf to accumulate detectable amounts of PepMoV CP was leaf 9 (petiole and blade) at $5 \mathrm{dpi}$, which was on the same side of the stem as inoculated leaf 1. By $6 \mathrm{dpi}$, the two youngest leaves (11 and 12) had accumulated detectable amounts of viral $\mathrm{CP}$, although it was localized in the major vein (data not shown). PepMoV CP was detected in the petiole and leaf blade of leaves 8 and 10 by $7 \mathrm{dpi}$, while detection in leaf 7 occurred at 12 dpi. In leaves 2 to 6 , unlike other leaves, there was a delay in detection of viral $\mathrm{CP}$ in the leaf blade versus the petiole. By 39 dpi, PepMoV CP was detected in the petiole and leaf blade of all leaves.

Phloem-dependent movement of PepMoV within the stem. Tissue prints of stem sections of 'Early Calwonder' plants inoculated with PepMoV onto leaf 1 are presented in Figure 1. Stem sections included in Figure 1 are the internode between the inoculated leaf and the cotyledonary node (A1-A4, below the inoculated leaf), the internode between uninoculated leaves 2 and 3 (B1-B4, above the inoculated leaf), and the internode between uninoculated leaves 6 and 7 (C1-C4, above the inoculated leaf). Represented plants were analyzed at 4 days $4 \mathrm{~h}$ postinoculation (pi) (row 1), 4 days $8 \mathrm{~h}$ pi (row 2), 5 days pi (row 3), and 6 days pi (row 4). The relative locations of external and internal phloem as indicated in Figure 1 were determined microscopically (discussed below in Microscopy). Each tissue print is in the same orientation whereby the side of the stem to which the inoculated leaf was attached faces the bottom. No antibody-antigen reaction was observed in any mock-inoculated samples throughout the course of these experiments.

The rapid rate of phloem-dependent translocation of PepMoV through the stem of 'Early Calwonder' plants was revealed during each of four experiments involving the generation of tissue prints at 4 -h intervals from 2 to $6 \mathrm{dpi}$. The time postinoculation at which

TABLE 1. Detection of pepper mottle potyvirus (PepMoV) coat protein antigen in the leaf blade (B) and petiole (P) of 'Early Calwonder' leaves through time

\begin{tabular}{|c|c|c|c|c|c|c|c|c|c|c|}
\hline \multirow{2}{*}{$\begin{array}{l}\text { Leaf } \\
\text { no. }\end{array}$} & \multirow{2}{*}{$\mathrm{B} / \mathrm{P}$} & \multicolumn{9}{|c|}{ Presence of PepMoV coat protein antigen ${ }^{\mathrm{a}}$} \\
\hline & & 4 dpi & 4.5 dpi & 5 dpi & $6 \mathrm{dpi}$ & $7 \mathrm{dpi}$ & 12 dpi & 18 dpi & $21 \mathrm{dpi}$ & 39 dpi \\
\hline \multirow[t]{2}{*}{12} & B & - & - & - & + & + & + & + & + & + \\
\hline & $\mathrm{P}$ & - & - & - & + & + & + & + & + & + \\
\hline \multirow[t]{2}{*}{11} & $\mathrm{~B}$ & - & - & - & + & + & + & + & + & + \\
\hline & $\mathrm{P}$ & - & - & - & + & + & + & + & + & + \\
\hline \multirow[t]{2}{*}{10} & B & - & - & - & - & + & + & + & + & + \\
\hline & $\mathrm{P}$ & - & - & - & - & + & + & + & + & + \\
\hline \multirow[t]{2}{*}{9} & B & - & - & + & + & + & + & + & + & + \\
\hline & $\mathrm{P}$ & - & - & + & + & + & + & + & + & + \\
\hline \multirow[t]{2}{*}{8} & B & - & - & - & - & + & + & + & + & + \\
\hline & $\mathrm{P}$ & - & - & - & - & + & + & + & + & + \\
\hline \multirow[t]{2}{*}{7} & B & - & - & - & - & - & + & + & + & + \\
\hline & $\mathrm{P}$ & - & - & - & - & - & + & + & + & + \\
\hline \multirow[t]{2}{*}{6} & B & - & - & - & - & - & - & - & - & + \\
\hline & $\mathrm{P}$ & - & - & - & - & - & - & + & + & + \\
\hline \multirow[t]{2}{*}{5} & B & - & - & - & - & - & - & - & - & + \\
\hline & $\mathrm{P}$ & - & - & - & - & - & - & + & + & + \\
\hline \multirow[t]{2}{*}{4} & B & - & - & - & - & - & - & - & - & + \\
\hline & $\mathrm{P}$ & - & - & - & - & - & + & + & + & + \\
\hline \multirow[t]{2}{*}{3} & B & - & - & - & - & - & - & - & + & + \\
\hline & $\mathrm{P}$ & - & - & - & - & - & + & + & + & + \\
\hline \multirow[t]{2}{*}{2} & B & - & - & - & - & - & - & - & + & + \\
\hline & $\mathrm{P}$ & - & - & - & - & - & + & + & + & + \\
\hline \multirow[t]{2}{*}{1} & B & - & + & + & + & + & + & + & + & + \\
\hline & $\mathrm{P}$ & - & + & + & + & + & + & + & + & + \\
\hline
\end{tabular}

a Data are presented to indicate detection (+) or lack of detection (-) of PepMoV coat protein antigen at the indicated sampling time. PepMoV coat protein antigen was detected using immunotissue blot analysis as described in Materials and Methods. Plants were analyzed from 4 through 39 days postinoculation (dpi).

${ }^{b}$ Leaves were numbered in a decreasing order of age from the oldest true leaf (leaf 1) to the youngest leaf (leaf 12).
PepMoV CP was first detected varied from one experiment to another and even from one plant to another; however, the relative rate of movement through the stem, once viral CP was detected, was similar. In a representative example, viral $\mathrm{CP}$ was first detected at 4 dpi in the internode below the inoculated leaf (between inoculated leaf and cotyledonary node) as a weak reaction in the form of a few spots associated with external phloem (data not shown). When plants were sampled $4 \mathrm{~h}$ later, however, a dramatic increase in viral CP accumulation was observed, and of particular interest was that PepMoV CP was detected in all stem sections from the cotyledonary node to near the apical bud (e.g., Fig. 1, $\mathrm{A} 1, \mathrm{~B} 1$, and C1). Thus, it appeared as though, once PepMoV CP was detected in the stem, subsequent movement and associated accumulation occurred very rapidly. Furthermore, the relative amount of viral $\mathrm{CP}$, based on intensity of the antibody-antigen reaction, that accumulated in external versus internal phloem below the inoculated leaf was not consistent from one plant to another and through time. For example, for some plants, the internode between the inoculated leaf and the cotyledons had more PepMoV CP in external than in internal phloem, while others had more viral $\mathrm{CP}$ in internal than in external phloem (e.g., Fig. 1, A2 and A3, respectively). In contrast, the pattern of PepMoV $\mathrm{CP}$ accumulation in internodes above the inoculated leaf tended to be very consistent in terms of the number of phloem bundles containing viral $\mathrm{CP}$ and the intensity of antibody-antigen reaction through time.

The pattern of phloem-dependent movement and timing of accumulation of PepMoV in all stem sections of 'Early Calwonder' plants above the cotyledonary node was the same in each experiment performed (Fig. 1 represents one experiment). At the internode between the inoculated leaf and the cotyledonary node, PepMoV CP was detected in the external phloem and weakly in the internal phloem (Fig. 1, A1). At all internodes above the inoculated leaf (Fig. 1, B1 and C1), viral CP was always detected only in internal phloem during the earlier stages of systemic infection. The number of cells within a tissue print that contained PepMoV increased during the course of the experiment (Fig. 1, rows 1 to 4). This was particularly true for sections representing the internode below the inoculated leaf and the internode between leaves 2 and 3 (Fig. 1, A1-A4 and B1-B4), where the entire pith area reacted strongly for the presence of PepMoV CP. Eventually, PepMoV CP was detected across entire tissue prints taken from sections throughout the stem (data not shown).

Consistent with the pattern of phloem-dependent movement of PepMoV described above was an asymmetry in this pattern within the stem. This was most obvious in samples representing earlier stages of systemic infection (e.g., Fig. 1, rows 1 and 2). PepMoV $\mathrm{CP}$ was always detected in the side of the stem to which the inoculated leaf was attached (bottom of each print in Fig. 1). This asymmetry in pattern of phloem-dependent movement occurred throughout the entire length of the stem including the hypocotyl. Once virus had traversed the length of the stem, subsequent movement appeared to occur in two forms: (i) between similar types of vascular tissues, e.g., between external phloem bundles (Fig. 1, A4 and B4) or between internal phloem bundles (Fig. 1, C1-C4), in each case resulting in a ringlike appearance of antigen-antibody reaction, and (ii) what appeared to be lateral spread, especially in the central pith portion of the stem. Whether movement of virus into adjacent tissues such as the pith was actually the result of a form of lateral movement was not determined, although it occurred acropetally (toward the apical bud), usually well after the time at which viral CP was first detected throughout the stem.

The pattern of PepMoV spread through the stem was consistent regardless of the position of the inoculated leaf, e.g., when leaf 5 was inoculated, viral $\mathrm{CP}$ was first detected in the external phloem at all internodes between the inoculated leaf and the cotyledonary node and then in internal phloem in all internodes from the cotyledonary node to the apical bud. In the hypocotyl, however, a pattern of detection of PepMoV CP in external or internal 
phloem tissues was not as easily defined. In some plants, viral $\mathrm{CP}$ was first observed in the external phloem within the hypocotyl region, while, in others, it occurred in the internal phloem (data not shown).
Consistent with this pattern of PepMoV phloem-dependent movement through the stem of 'Early Calwonder' plants was the pattern observed for a second distinct isolate of PepMoV and two isolates of TEV. In addition, a similar pattern for viral translocation through

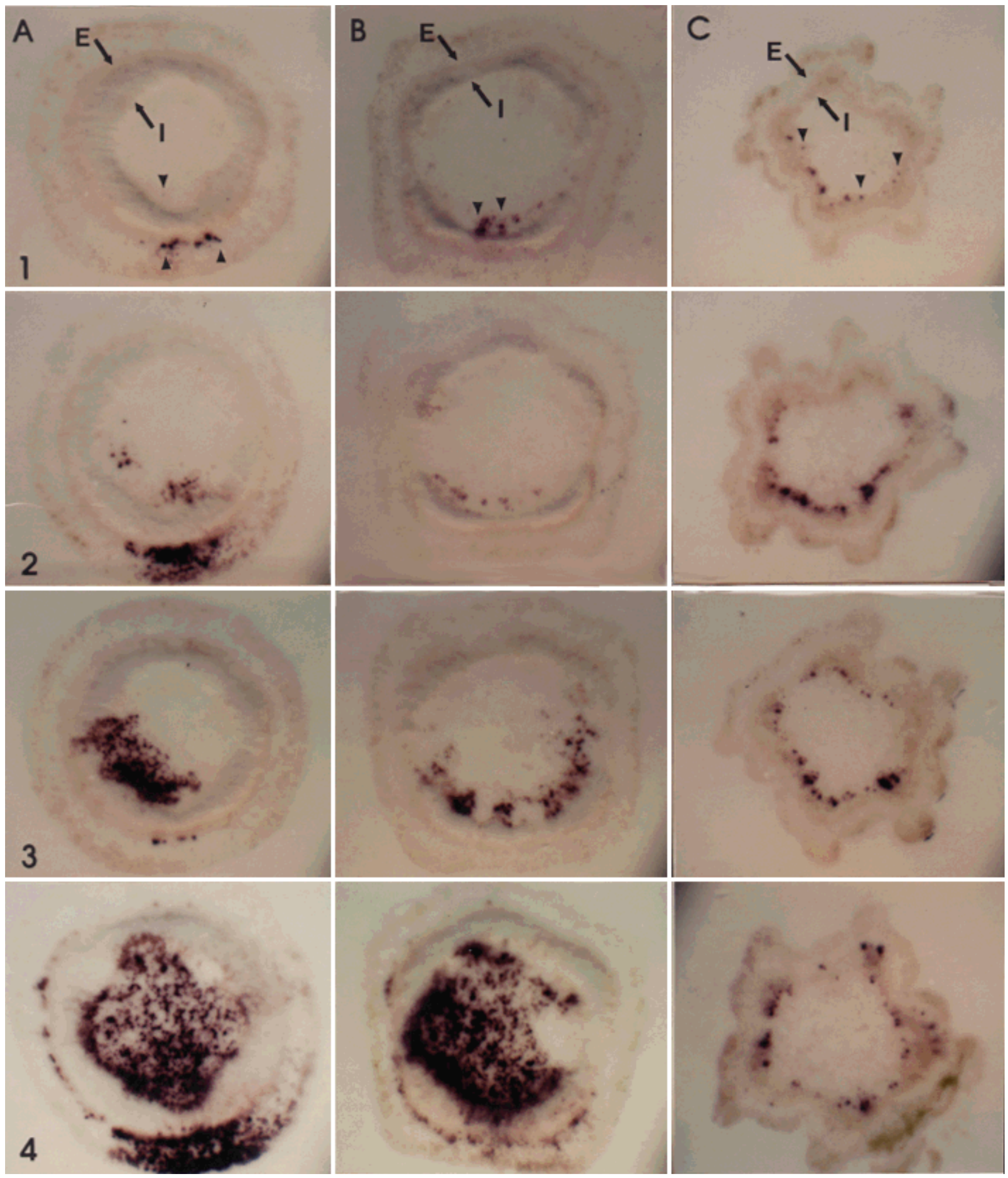

Fig. 1. Immunotissue blot analysis of 'Early Calwonder' stem sections for the presence of pepper mottle potyvirus (PepMoV) coat protein antigen. The tissue prints represent stem sections from internodes A, below the inoculated leaf (between the inoculated leaf and the cotyledons, A1-A4) and B and C, above the inoculated leaf (between leaves 2 and 3, B1-B4; and between leaves 6 and 7, C1-C4). Plants were sampled at 4 days 4 h postinoculation (pi) (row 1), 4 days $8 \mathrm{~h}$ pi (row 2), 5 days pi (row 3), and 6 days pi (row 4). The relative location of external and internal phloem are noted by an E and an I, respectively. Arrow heads point to examples of antibody-antigen reactions. 
the stem occurred in the $C$. annuum varieties 'Jupiter' and 'Avelar' (J. F. Murphy, unpublished data). Thus, the pattern phloem-dependent movement through the stem of Capsicum was similar for different potyviruses and in different $C$. annuum genotypes.

Microscopy. Internal phloem is a general feature of the Solanaceae, the family to which Capsicum belongs (33). Microscopic analyses were carried out to confirm the existence of external and
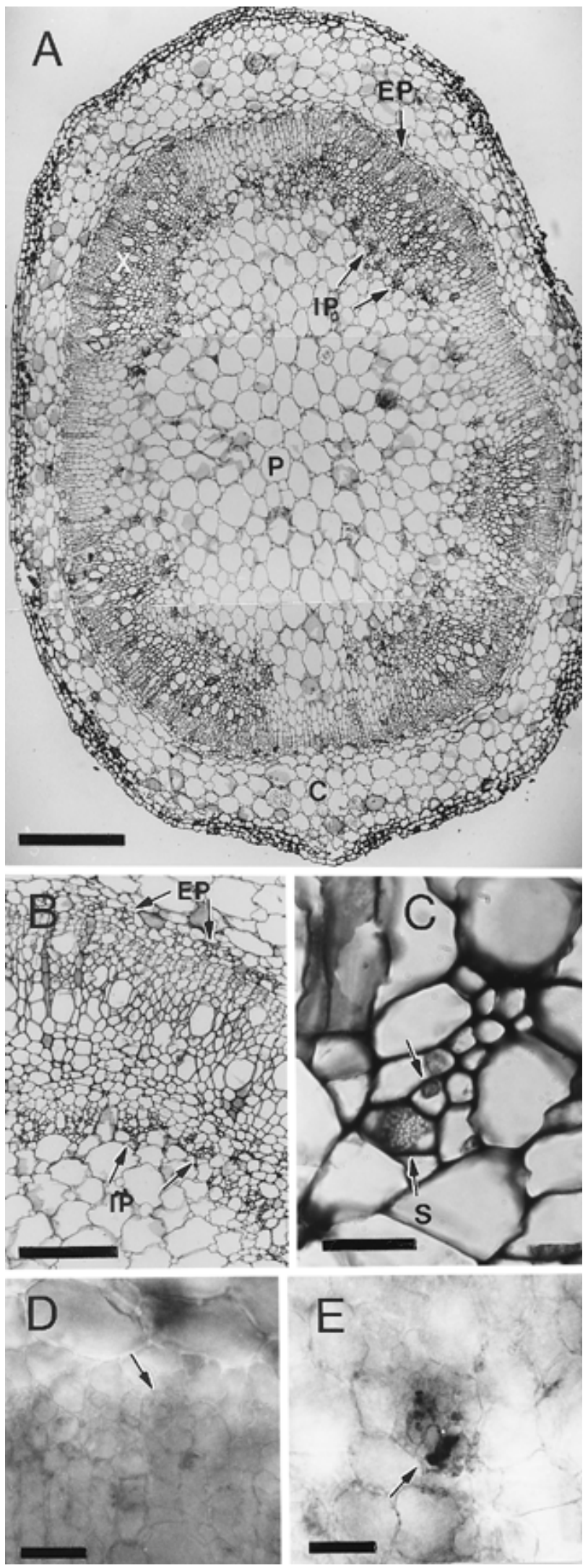

internal phloem bundles in $C$. annuum 'Early Calwonder' plants and their association with virus transport. Stem shape varied depending on location, e.g., below leaves 1 and 2, the stem tended to have rounded edges, while progression up the stem revealed a more irregularly shaped, angular stem periphery. Regardless of its apparent shape, the general internal anatomical features were consistent throughout the length of the stem. Within an internode, there was a ring of vascular tissues that consisted of external phloem surrounding xylem tissue (Fig. 2A and B). Phloem bundles (Fig. 2A and B) also occurred internal to the xylem. Closer examination of internal phloem bundles revealed sieve-tube members with sieve plates and companion cells with prominent nuclei (Fig. 2C). The same cell types were present in the external phloem. Anatomy of the nodal regions of the stem was similar to that of the internodes, except that the vascular cylinder was interrupted by leaf gaps (data not shown).

Microscopic analysis combined with immunogold labeling and silver enhancement was used to identify those tissues in which PepMoV accumulated (Fig. 2D and E). In stem segments above the inoculated leaf, no PepMoV CP was detected in external phloem (Fig. 2D), but viral $\mathrm{CP}$ was detected in the internal phloem (Fig. 2E). PepMoV CP was detected in both external phloem and internal phloem in stem segments from between the inoculated leaf and the cotyledonary node (data not shown).

\section{DISCUSSION}

We have shown that the phloem-dependent accumulation of PepMoV in stems of 'Early Calwonder' plants occurs in a defined pattern that we suggest represents the route by which virus translocates rapidly to younger tissues. PepMoV CP was consistently detected in external and internal phloem of the stem in the internode below the inoculated leaf (between the inoculated leaf and the cotyledonary node). Occasionally, viral CP was only detected in the external phloem at the earliest stages of detection, and this was particularly apparent when a younger leaf (e.g., leaf 5) was inoculated (data not shown). In every case, however, PepMoV CP was detected initially only in internal phloem in tissue prints representing stem sections above the inoculated leaf. These data, along with knowledge of anatomical features of plants within the family Solanaceae and source-to-sink translocation of substances within the phloem, are used to explain the phloem-dependent translocation of PepMoV through Capsicum plants.

The lag period observed between the time of inoculation and first detection of PepMoV CP in the inoculated leaf represents initial stages of infection, e.g., accumulation of virus and viral gene products within the initially infected cells with subsequent spread to neighboring cells. Once virus enters phloem tissues within the inoculated leaf, the rate of transport through the leaf vasculature, petiole, and into the stem is rapid and determined by source-sink relationships.

Fig. 2. Microscopic analysis of Capsicum апnиит stem segments. A through C, Stained sections of paraffin-embedded material. D and E, Unstained free-hand sections. A, Cross section of the stem at the internode between cotyledonary node and the first leaf. $\mathrm{C}=$ cortex, $\mathrm{EP}=$ external phloem, $\mathrm{IP}=$ internal phloem, $\mathrm{P}=$ pith, and $\mathrm{X}=$ xylem. Bar equals $0.5 \mathrm{~mm} . \mathbf{B}, \mathrm{A}$ closer view of the stem vasculature showing external phloem (EP) and internal phloem (IP) bundles. Bar equals $0.2 \mathrm{~mm}$. C, An internal phloem bundle; note the sieve plate (S) and a companion cell with a prominent nucleus (unlabeled arrow). Bar equals $0.02 \mathrm{~mm}$. D and E, Sections illustrating external and internal phloem bundles (unlabeled arrows), respectively, from a stem segment above the inoculated leaf taken at 6 days postinoculation. Sections were treated with anti-pepper mottle potyvirus (PepMoV) antibody followed by gold-conjugated goat anti-rabbit antibody and visualized after silver enhancement. D, No PepMoV antigen was detected in external phloem, while E, PepMoV antigen was detected in internal phloem. Bar equals $0.05 \mathrm{~mm}$. 
Upon exiting the inoculated leaf, virus is initially localized in the external phloem of the subtending internode. Leaf veins and petioles of the family Solanaceae have both abaxial and adaxial phloem strands that correspond to external and internal phloem of the stem, respectively $(19,31,32)$. Experimental evidence shows that it is the abaxial phloem that is associated with sugar export from the leaf $(5,37,44)$. This feature would explain the initial appearance of PepMoV in the external phloem; it is external phloem of the stem that primarily or exclusively transports photoassimilates in a descending direction from leaves to roots (6). This phloem-dependent translocation of virus down the stem from the inoculated leaf prior to translocation up the stem to young tissues has been described for other viral systems $(27,29,39)$. PepMoV appeared to spread in the external phloem to some locale within or beneath the cotyledonary node, where it then had access to internal phloem or some type of connective channel between external and internal phloem (discussed below). Upon entrance into the internal phloem, it then translocated rapidly to the apical portion of the plant via this same tissue, which transports photoassimilates in an ascending direction to young tissues that are functionally active sinks for photoassimilates (6). This would explain detection of PepMoV in external and internal phloem in the internode below the inoculated leaf, but only in the internal phloem in internodes above the inoculated leaf. External and internal phloem tissues in leaf mid-veins, petioles, and stems of potato plants were identified as paths of translocation for potato leafroll luteovirus (PLRV) $(3,13)$. Interestingly, a clear distinction in route of movement was not identified, although there was a reduction in the number of external phloem cells containing detectable amounts of PLRV in the resistant variety (13).

The location within the stem where PepMoV enters the internal phloem has not been determined. During the course of several experiments, viral CP was detected in external and internal phloem from stem sections taken below the inoculated leaf, while only in the internal phloem from stem sections taken above the inoculated leaf. It should also be noted that, in some plants, PepMoV CP was not detected in external or internal phloem of the hypocotyl prior to detection in the internal phloem of stem sections above the inoculated leaf. These data suggest that movement from external to internal phloem (with subsequent movement up the stem) occurred in the region of the cotyledonary node. It is known from potato (2), tobacco (17), and plants within the family Solanaceous in general (6) that internal and external phloem bundles exhibit connections through leaf gaps at the nodal regions of a stem. The cotyledonary node would, therefore, be a prime site for exchange of material coming from the first true leaf. Additional experiments, however, revealed that the time until detection of PepMoV $\mathrm{CP}$ within the cotyledonary node and the hypocotyl relative to detection above the inoculated leaf was inconsistent and could have represented stem sections in which virus had passed through but had not accumulated to detectable levels. Samuel (39) described a similar phenomenon with tobacco mosaic tobamovirus in tomato. Moreover, connections between external and internal phloem are also located within the hypocotyl of plants within the family Solanaceous such as potato and tomato (19) and could represent other pathways by which virus could exit one tissue and enter another.

The upward path of virus movement in the internal phloem appears to be a direct one (in discussion below regarding leaves). Initially, an arc-shaped distribution of cells containing PepMoV $\mathrm{CP}$ was observed in the internal phloem. The arc increased in circumference with time to give a ringlike appearance of antibodyantigen reaction. This spread of PepMoV to adjacent internal phloem bundles may have occurred via lateral anastomoses that occur for both internal and external phloem of tobacco (17). In contrast, movement from internal phloem to pith might have occurred via plasmodesmata.

The general pattern of translocation of PepMoV into different leaves of 'Early Calwonder' plants followed a source-to-sink pattern for the flow of photoassimilates similar to that described for other virus/host systems $(27,29,39)$. The detection of PepMoV in leaf 9 before detection in any other leaf, and in particular leaf 10, which was at a similar developmental stage as leaf 9, may be explained by the pattern of viral phloem-dependent movement through the stem. The vascular system of the stem consists of a sympodium of leaf traces. It has been shown in tobacco that those leaves on the same side of the stem have traces adjacent to one another in the vascular cylinder (18). Thus, material in the phloem of the inoculated leaf would quickly spread to adjacent traces and would then be carried upward. This holds true for sugars (23) as well as for viruses (18). The same seems to be true of $C$. апnиum such that the translocation of assimilates via the internal phloem feeds directly into leaves that are functionally active as sinks, with leaves located on the same side of the stem as the source leaf receiving assimilates prior to leaves located on different sides of the stem. PepMoV would, therefore, be translocated to leaf 9 first, since leaf 9 is on the same side of the stem as the source of inoculum, whereas leaf 10 is on the opposite side. An asymmetry in systemic phloemdependent translocation and accumulation was also observed for cauliflower mosaic caulimovirus (CaMV) in turnip plants (27) and for cherry leafroll nepovirus in tobacco plants (29). The translocation of CaMV was correlated with that of ${ }^{14} \mathrm{CO}_{2}$ in turnip plants to show that phloem-dependent movement of assimilates and virus from inoculated leaves to younger uninoculated leaves occurred in a predictable manner. Younger leaves located on the same side of the stem as the inoculated leaf accumulated $\mathrm{CaMV}$ and ${ }^{14} \mathrm{CO}_{2}$ prior to other leaves, indicating that photoassimilates and virus from source leaves translocated up the stem initially in an asymmetric manner to sinks that occurred on the same side of the stem as the source (27).

In contrast to younger leaves, leaves 5 and 6 were the last to accumulate detectable amounts of PepMoV CP. These leaves may have been sources of photoassimilates rather than sinks; however, this is confounded by leaves 2,3 , and 4 , which were older than leaves 5 and 6 , but had accumulated detectable amounts of viral $\mathrm{CP}$ before leaves 5 and 6 . It has been shown that, once leaves have become sucrose exporters, they will import only with difficulty, if at all $(8,44)$. Spread of PepMoV into leaves 2 to 6 may have occurred via cell-to-cell movement rather than in a source-to-sink manner, with each leaf becoming infected as virus progressively moved up the stem.

In summary, it appears that phloem-dependent movement of PepMoV (and other potyviruses) through the stem of $C$. annuum occurs in a defined manner that involves descending transport via the external phloem in the stem from the inoculated leaf, with rapid translocation to young tissues occurring via the internal phloem. This process occurs in an asymmetric fashion through the length of the stem, i.e., it occurs on the same side of the stem to which the inoculated leaf is attached. The location at which virus enters the internal phloem was not determined; however, it appears to be within or below the cotyledonary node.

\section{ACKNOWLEDGMENTS}

This work was supported, in part, by a grant from the Auburn University Competitive Grand-in-Aid Program. Alabama Agricultural Experiment Station System journal number 18-965730. We thank K. L. Bowen, C. M. Deom, J. W. Kloepper, and C. Lawrence for critical review of the manuscript.

\section{LITERATURE CITED}

1. Agrios, G. N. 1988. Plant Pathology. 3rd ed. Academic Press, New York.

2. Artschwager, E. F. 1918. Anatomy of the potato plant, with special reference to the ontogeny of the vascular system. J. Agric. Res. 14:221-252.

3. Barker, H., and Harrison, B. D. 1986. Restricted distribution of potato leafroll virus antigen in resistant potato genotypes and its effect on transmission of the virus by aphids. Ann. Appl. Biol. 109:595-604.

4. Bennett, C. W. 1940. Relation of food translocation to movement of virus of tobacco mosaic. J. Agric. Res. 60:361-390. 
5. Bonnemain, J. L. 1969. Transport du ${ }^{14} \mathrm{C}$ assimile a partir des feuilles de tomate en voie de croissance et vers celles-ci. C. R. Acad. Sci. 269: 1660-1663.

6. Bonnemain, J. L. 1969. Le phloème interne et le phloème inclus des dicotylédonnes, leur histogénèse et leur physiologie. Rev. Gen. Bot. 76:5-36.

7. Brunt, A., Crabtree, K., and Gibbs, A. 1990. Viruses of Tropical Plants. Redwood Press Ltd., Melksham, Wiltshire, United Kingdom.

8. Canny, M. J. 1962. The mechanism of translocation. Ann. Bot. 26:603-617.

9. Citovsky, V., and Zambryski, P. 1991. How do plant virus nucleic acids move through intercellular connections? BioEssays 13:373-379.

10. Citovsky, V., and Zambryski, P. 1993. Transport of nucleic acids through membrane channels: Snaking through small holes. Annu. Rev. Microbiol. 47:167-197.

11. Cronin, S., Verchot, J., Haldeman-Cahill, R., Schaad, M. C., and Carrington, J. C. 1995. Long-distance movement factor: A transport function of the potyvirus helper component proteinase. Plant Cell 7:549-559.

12. Deom, C. M., Lapidot, M., and Beachy, R. N. 1992. Plant virus movement proteins. Cell 69:221-224.

13. Derrick, P. M., and Barker, H. 1997. Short and long distance spread of potato leafroll luteovirus: Effect of host genes and transgenes conferring resistance to virus accumulation in potato. J. Gen. Virol. 78:243-251.

14. Ding, X. S., Shintaku, M. H., Arnold, S. A., and Nelson, R. S. 1995. Accumulation of mild and severe strains of tobacco mosaic virus in minor veins of tobacco. Mol. Plant-Microbe Interact. 8:32-40.

15. Dolja, V. J., Haldeman, R., Robertson, N. L., Dougherty, W. G., and Carrington, J. C. 1994. Distinct functions of capsid protein in assembly and movement of tobacco etch potyvirus in plants. EMBO (Eur. Mol. Biol. Organ.) J. 6:1482-1491.

16. Dolja, V. J., Haldeman-Cahill, R., Montgomery, A. E., Vandenbosch, K. A., and Carrington, J. C. 1995. Capsid protein determinants involved in cell-to-cell and long-distance movement of tobacco etch potyvirus. Virology 206:1007-1016.

17. Esau, K. 1938. Ontogeny and structure of the phloem of tobacco. Hilgardia 11:343-424.

18. Esau, K. 1941. Phloem anatomy of tobacco affected with curly top and mosaic. Hilgardia 13:437-490.

19. Hayward, H. E. 1938. The Structure of Economic Plants. Macmillan Company, New York.

20. Holt, C. A., and Beachy, R. N. 1991. In vivo complementation of infectious transcripts from mutant tobacco mosaic virus cDNAs in transgenic plants. Virology 181:109-117.

21. Hull, R. 1989. The movement of viruses in plant. Annu. Rev. Phytopathol. 27:213-240.

22. Jensen, W. 1962. Botanical Histochemistry Principles and Practice. P. P. Freeman and Company, San Francisco, CA.

23. Jones, H., Martin, R. V., and Porter, H. K. 1959. Translocation of ${ }^{14}$ carbon in tobacco following assimilation of ${ }^{14}$ carbon dioxide by a single leaf. Ann. Bot. 23:493-508.

24. Kasteel, D., Wellink, J., Verver, J., van Lent, J., Goldbach, R., and van Kammen, A. 1993. The involvement of cowpea mosaic virus M RNAencoded proteins in tubule formation. J. Gen. Virol. 74:1721-1724.
25. Leary, J. J., Brigati, D. J., and Ward, D. C. 1983. Rapid and sensitive colorimetric method for visualizing biotin-labeled DNA probes hybridized to DNA or RNA immobilized on nitrocellulose: Bio-blots. Proc. Natl. Acad. Sci. U.S.A. 80:4045-4049.

26. Leisner, S. M., and Turgeon, R. 1993. Movement of virus and photoassimilate in the phloem: A comparative analysis. BioEssays 15:741-748.

27. Leisner, S. M., Turgeon, R., and Howell, S. H. 1992. Long distance movement of cauliflower mosaic virus in infected turnip plants. Mol. Plant-Microbe Interact. 5:41-47.

28. Lucas, W. J., and Gilbertson, R. L. 1994. Plasmodesmata in relation to viral movement within leaf tissues. Annu. Rev. Phytopathol. 32:387-411.

29. Mas, P., and Pallas, V. 1996. Long-distance movement of cherry leaf roll virus in infected tobacco plants. J. Gen. Virol. 77:531-540.

30. Maule, A. J. 1991. Virus movement in infected plants. Crit. Rev. Plant Sci. 9:457-473.

31. McCauley, M. M., and Evert, R. F. 1988. Morphology and vasculature of the leaf of potato (Solanum tuberosum). Am. J. Bot. 75:377-390.

32. McCauley, M. M., and Evert, R. F. 1988. The anatomy of the leaf of potato, Solanum tuberosum L. 'Russet Burbank'. Bot. Gaz. 149:179-195.

33. Metcalfe, C. R., and Chalk, L. 1950. Anatomy of the Dicotyledons. Claredon Press, Oxford.

34. Murphy, J. F., and Kyle, M. M. 1995. Alleviation of the restricted systemic spread of pepper mottle potyvirus in Capsicum annuиm cv. Avelar by coinfection with a cucumovirus. Phytopathology 85:561-566.

35. Murphy, J. F., Rhoads, R. E., and Hunt, A. G. 1990. The VPg of tobacco etch virus RNA is the 49-kDa proteinase or the N-terminal 24-kDa part of the proteinase. Virology 178:285-288.

36. O'Brien, T. P., Feder, N., and McCully, M. E. 1964. Polychromatic staining of plant cell walls by toluidine blue O. Protoplasma 54:368-373.

37. Peterson, C. A., and Currier, H. B. 1969. An investigation of bidirectional translocation in the phloem. Physiol. Plant 22:1238-1250.

38. Ritzenthaler, C., Schmit, A.-C., Michler, P., Stussi-Garaud, C., and Pinck, L. 1995. Grapevine fanleaf nepovirus P38 putative movement protein is located on tubules in vivo. Mol. Plant-Microbe Interact. 8:379-387.

39. Samuel, G. 1934. The movement of tobacco mosaic virus within the plant. Ann. Appl. Biol. 21:90-111.

40. Swiader, J. M., Ware, G. W., and McCollum, J. P. 1992. Producing Vegetable Crops. 4th ed. Interstate Publishers, Danville, IL.

41. Thresh, J. M. 1978. The epidemiology of plant virus diseases. Pages 7991 in: Plant Disease Epidemiology. Halsted Press, New York.

42. Tomlinson, J. A. 1986. Epidemiology and control of virus diseases of vegetables. Ann. Appl. Biol. 110:661-681.

43. Turgeon, R. 1989. The source-sink transition in leaves. Annu. Rev. Plant Physiol. Plant Mol. Biol. 40:119-138.

44. Turgeon, R., and Webb, J. A. 1976. Leaf development and phloem transport in Cucurbita pepo: Maturation of the minor veins. Planta 129:265-269.

45. van Lent, J., Storms, M., van der Meer, F., Wellink, J., and Goldbach, R. 1991. Tubular structures involved in movement of cowpea mosaic virus are also formed in infected cowpea protoplasts. J. Gen. Virol. 72:2615-2623.

46. Walkey, D. G. A. 1985. Applied Plant Virology. John Wiley \& Sons, New York 